\title{
REFERENCES
}

DE Sitter, L. U., 1957. Cleavage Folding in Relation to Sedimentary Structure. International Geological Congress, 20th Session, Mexico (1956). Section V, 53-64.

1958. Boudins and Parasitic Folds in Relation to Cleavage and Folding. Geol. en Mijnbouw, 20, 277-286.

FYson, W. K., 1962. Tectonic Structures in the Devonian Rocks near Plymouth, Devon. Geol. Mag., 99, 208-226.

Ramberg, H., 1963. Evolution of Drag Folds. Geol. Mag., 100, 97-105.

RAMSAY, J. G., 1962. The Geometry and Mechanics of Formation of "Similar" Type Folds. Jour. Geol., 70, 309-327.

Williams, E., 1959. The Sedimentary Structures of the Upper Scamander Sequence and their Significance. Pap. Proc. Roy. Soc. Tas., 93, 29-32.

1961a. The Deformation of Confined, Incompetent Layers in Folding. Geol. Mag., 98, 317-323.

1961b. Flow Folding in Rocks. Nature, 189, 474-5.

Department of Mines,

EMYR WILlIAMS.

G.P.O. BOX 124B,

HOBART, TASMANia.

22nd July, 1963.

\section{THE STATUS OF THE ORDOVICIAN TRILOBITE GENERA PRIONOCHEILUS AND POLYERES}

SIR,-In 1847, in papers describing the faunas of Ille-et-Vilaine and the district around Rennes, Marie Rouault created two trilobite genera, namely Prionocheilus and Polyeres. Prionocheilus was erected on the basis of a single species, $P$. verneuili Rouault, whilst Polyeres was founded similarly on $P$. dufrenoyi Rouault. Each of these is thus the type-species of the genus by monotypy. Rouault's results constituted part of a larger work and those published by him in 1847 are divided into two small papers, separated by a few lines of discussion and referred to here as Rouault, $1847 a$ and $1847 b$. In the first paper the characteristic features of several trilobites, including Prionocheilus and Polyeres, were tabulated (Rouault, 1847a, table opp. p. 318) but as no species were mentioned these two generic names became available. The second paper again listed the two genera, but this time each was accompanied by a (type) species and briefly diagnosed. There can thus be no doubt of their validity.

Prionocheilus verneuili Rouault $(1847 b$, p. 320, pl. 3, figs. 3, 3a) was described and illustrated from the Middle Ordovician of Poligné, Brittany. In the same year Hawle and Corda $(1847$, p. 88$)$ erected the genus Pharostoma, founded on Calymene pulchra Beyrich, 1846, from the Middle Ordovician of Bohemia. That the two are congeneric is generally agreed, and it has been assumed that Pharostoma takes precedence over Prionocheilus, the differences between the two type-species having been noted by Whittard $(1960$, p. 137) However, in re-describing and figuring the type-material of Prionocheilus vernewili in "Palaeontologia Universalis", Bézier (1907) stated that the genus had priority over Pharostoma, though he gave no detailed reasons for his opinion, which has been generally overlooked. Dr. Alois Prribyl of Prague has kindly informed me (in litt.) that Hawle and Corda's well-known "Prodrom einer monographie der böhmischen trilobiten" was published late in July, 1847. The date of Rouault's 1847 paper has proved more difficult to trace owing to the fact that most copies, including that of the Société géologique de France in Paris, lack the original cover. However, the copy at the British Museum, Bloomsbury, retains the cover and Mr. S. F. Morris has confirmed that the paper was published in April, 1847, as was noted by 
Clarke (1892, footnote to p. 8). It is clear, therefore, that Prionocheilus antedates Pharostoma by some three months and so must take precedence.

The type-species of Polyeres, $P$. dufrenoyi Rouault $(1847 \mathrm{~b}, \mathrm{p}$. 320), like that of Prionocheilus, was obtained from the Middle Ordovician of Poligné, but a full description and illustration have yet to be published. In spite of this, however, it has been generally known for many years that Polyeres is congeneric with Selentopeltis Hawle and Corda, 1847, type-species Odontopleura inermis Beyrich, 1846 [= Odontopleura buchi Barrande, 1846], and the two genera have been discussed by both Clarke $(1892$, p. 96) and Prantl and Pribyl (1949, p. 176). From a classificatory point of view, even though Prionocheilus and Polyeres must now be held to have priority over Pharostoma and Selenopeltis the subfamilial names Prionocheilinae and Polyerinae are inadmissible so long as Article 40 of the International Code of Zoological Nomenclature is in force. The systematic position of the two genera may be summarized as follows:-

Family Calymenidae Burmeister, 1843

Subfamily Pharostomatinae Hupé, 1953.

Genus Prionocheilus Rouault, 1847 [ $\approx$ Pharostoma Hawle and Corda, 1847 subj. syn.].

Type species: $P$. verneuili Rouault, 1847 by monotypy.

Family Odontopleuridae Burmeister, 1843.

Subfamily Selenopeltinae Hawle and Corda, 1847.

Genus Polyeres Rouault, 1847 [ = Selenopeltis Hawle and Corda, 1847 subj. syn.].

Type species: $P$. dufrenoyi Rouault, 1847 by monotypy.

\section{REFERENCES}

BÉZIER, T., 1907. Prionocheilus Verneuili Rouault, 1847. In Palaeontologia Universalis, Paris, 1, 120.

Clarke, J. M., 1892. Notes on the genus Acidaspis. N.Y. State Mus., 44th Ann. Rep., 91.

HAWle, I., and A. J. C. CORDA, 1847. Prodrom einer monographie der böhmischen trilobiten. Prague.

Prantl, F., and A. Př́rYl, 1949. Studie o Trilobitech Nadceledi Odontopleuracea nov. superfam. Czechoslovakia, Státni. Geol. Ústav, Rozpravy (Praha), 12.

Rouault, M., 1847a. Extrait du Mémoire sur les trilobites du départment d'Ille-et-Vilaine. Soc. géol. France, Bull., (2), 4, 309.

- 1847b. Catalogue des fossiles du terrain paléozoique des environs de Rennes. Ibid., (2), 4, 320.

WhitTard, W. F., 1960. The Ordovician trilobites of the Shelve Inlier, West Shropshire, 4. Palaeontogr. Soc. [Monogr.], 117.

W. T. Dean.

British Museum (Natural History),

CromWell RoAD,

LONDON, S.W. 7.

5th December, 1963. 